University of Montana

ScholarWorks at University of Montana

Integrative Physiology and Athletic Training

Faculty Publications

Integrative Physiology and Athletic Training

$9-2006$

\title{
Blood Leukocyte mRNA Expression for IL-10, IL-1Ra, and IL-8, but Not IL-6, Increases After Exercise
}

\author{
David Nieman \\ Appalachian State University \\ Dru Henson \\ Appalachian State University \\ J. Mark Davis \\ University of South Carolina - Columbia \\ Charles Dumke \\ University of Montana - Missoula, charles.dumke@umontana.edu \\ Alan C. Utter \\ Appalachian State University \\ See next page for additional authors
}

Follow this and additional works at: https://scholarworks.umt.edu/hhp_pubs

Part of the Medicine and Health Sciences Commons

Let us know how access to this document benefits you.

\section{Recommended Citation}

Dr. David C. Nieman, Dru A. Henson, J. Mark Davis, Charles I. Dumke, Alan C. Utter, E. Angela Murphy, Steven Pearce, Greg Gojanovich, Steven R. McAnulty, and Lisa S. McAnulty. Journal of Interferon \& Cytokine Research. September 2006, 26(9): 668-674. doi:10.1089/jir.2006.26.668.

This Article is brought to you for free and open access by the Integrative Physiology and Athletic Training at ScholarWorks at University of Montana. It has been accepted for inclusion in Integrative Physiology and Athletic Training Faculty Publications by an authorized administrator of ScholarWorks at University of Montana. For more information, please contact scholarworks@mso.umt.edu. 


\section{Authors}

David Nieman, Dru Henson, J. Mark Davis, Charles Dumke, Alan C. Utter, E. Angela Murphy, Steven Pearce, Greg Gojanovich, Steven R. McAnulty, and Lisa S. McAnulty 


\title{
Blood Leukocyte mRNA Expression for IL-10, IL-1Ra, and IL-8, but Not IL-6, Increases After Exercise
}

\author{
DAVID C. NIEMAN,${ }^{1}$ DRU A. HENSON,${ }^{1}$ J. MARK DAVIS,${ }^{2}$ CHARLES L. DUMKE,${ }^{1}$ \\ ALAN C. UTTER, ${ }^{1}$ E. ANGELA MURPHY,${ }^{2}$ STEVEN PEARCE, ${ }^{1}$ GREG GOJANOVICH, ${ }^{1}$ \\ STEVEN R. MCANULTY, ${ }^{1}$ and LISA S. MCANULTY ${ }^{1}$
}

\begin{abstract}
The primary purpose of this project was to study exercise-induced leukocyte cytokine mRNA expression. Changes in plasma cytokine levels and blood leukocyte mRNA expression for interleukin-6 (IL-6), IL-8, IL10, and IL-1 receptor antagonist (IL-1Ra) were measured in 12 athletes following $2 \mathrm{~h}$ of intensive cycling $\left(\sim 64 \%\right.$ Watts $\left._{\max }\right)$ while ingesting a carbohydrate or placebo beverage (randomized and double blinded). Blood samples were collected $30 \mathrm{~min}$ preexercise and immediately and $1 \mathrm{~h}$ postexercise. Carbohydate compared with placebo ingestion attenuated exercise-induced changes in plasma cortisol (8.8\% vs. 62\%, respectively), epinephrine (-9.2\% vs. $138 \%$ ), IL-6 (10-fold vs. 40-fold), IL-10 (8.9-fold vs. 26-fold, and IL-1Ra (2.1-fold vs. 5.6-fold). Significant time effects were measured for blood leukocyte IL-8 (2.4-fold increase $1 \mathrm{~h}$ postexercise), IL-10 (2.7-fold increase), IL-1Ra (2.2-fold increase), and IL-6 (0.8-fold decrease) mRNA content, with no significant differences between Cho and Pla test conditions. In summary, gene expression for IL-8, IL-10, and IL-1Ra, but not IL-6, is increased in blood leukocytes taken from athletes following $2 \mathrm{~h}$ of intensive cycling and is not influenced by carbohydrate compared with placebo ingestion. mRNA expression was high enough to indicate a substantial contribution of blood leukocytes to plasma levels of IL-8, IL-10, and IL-1Ra during prolonged exercise.
\end{abstract}

\section{INTRODUCTION}

A MARKED INCREASE IN THE PLASMA concentrations of several cytokines, including interleukin-6 (IL-6), IL-10, IL-8, IL1 receptor antagonist (IL-1Ra), granulocyte colony-stimulating factor (G-CSF), monocyte chemoattractant protein-1 (MCP-1), and macrophage inflammatory protein- $1 \beta$ (MIP-1 $\beta)$, occurs in response to prolonged and intensive exercise. ${ }^{1-7}$ Sources of production of these cytokines are still being explored.

After heavy exercise workloads, the mRNA content for tumor necrosis factor- $\alpha$ (TNF- $\alpha$ ), IL-8, IL- $1 \beta$, and IL- 6 within muscle biopsy samples is increased, with the greatest fold increases measured for IL-6 and IL-8 mRNA (20-30-fold change from rest when rest $=1)^{2,3,8-12}$ Although muscle cells produce most of the IL-6 during exercise, ${ }^{11-13}$ production of other cytokines within muscle biopsy samples may come from several types of cells. Blood mononuclear cells do not appear to contribute IL- $1 \beta$, TNF$\alpha$, or IL-6 during sustained exercise. ${ }^{10,14}$ In a previous study, we noted that IL-8 mRNA expression was highest in postexercise muscle biopsy samples that visually appeared to have the most blood. ${ }^{2}$ IL- 8 is produced by a variety of cells throughout the body, including endothelial cells and blood mononuclear cells, ${ }^{15}$ but the primary source during exercise is unknown. Recently, Akerstrom et al. ${ }^{16}$ showed that IL-8 protein expression occurred within the cytoplasm of muscle fibers following $3 \mathrm{~h}$ of bicycle exercise but could not rule out contributions from other cell types, including endothelial cells and leukocytes. The anti-inflammatory cytokines IL-10 and IL-1Ra are derived from a variety of cell sources, including blood monocytes, but sources of production during exercise have not yet been determined. Ostrowski et al. ${ }^{10}$ proposed that exercise triggers IL-6 production within muscle cells, leading to a stimulation of IL-1Ra release from circulating blood mononuclear cells. Steensberg et al. ${ }^{17}$ showed that infusion of recombinant human IL-6 (rHuIL-6) increased plasma IL-1Ra and IL-10 levels compared with saline infusion but did not identify the sources of production.

\footnotetext{
${ }^{1}$ Departments of Health, Leisure, and Exercise Science, Biology, Family and Consumer Sciences, Fischer Hamilton/Nycom Biochemistry Laboratory, Appalachian State University, Boone, NC 28608.

${ }^{2}$ Department of Exercise Science, University of South Carolina, Columbia, SC 29208.
} 
In multiple studies, we and others have shown that carbohydrate compared with placebo ingestion attenuates exerciseinduced increases in blood neutrophils, monocyte, $\mathrm{T}$, and natural killer (NK) cell counts, plasma cortisol, epinephrine, IL-6, IL-10, and IL-1Ra, but not IL-8. ${ }^{1-3,5,6,9,18-26}$ Carbohydrate may exert these effects through multiple mechanisms, including elevation in blood glucose and tissue glucose uptake, decreases in cytokine mRNA expression, reductions in proinflammatory signals, and an attenuation of IL-6 release from the working muscle tissue. ${ }^{1,3,6,17,19}$ Carbohydrate ingestion during prolonged exercise permits investigation of the relative importance of these stimuli under randomized, placebo-controlled conditions.

The purpose of this project was to study the effect of carbohydrate compared with placebo ingestion on plasma hormone and cytokine levels and leukocyte cytokine mRNA expression following $2 \mathrm{~h}$ of intensive cycling. We hypothesized that carbohydrate compared with placebo ingestion would attenuate plasma hormone and cytokine levels after exercise. Based on limited information, we also hypothesized that blood leukocyte mRNA for IL-10, IL-8, IL-1Ra, but not IL-6, would increase during exercise, but not to the same magnitude during the carbohydrate trials. The cytokines measured in this study are based on prior studies showing that of plasma cytokines measured to date by exercise immunologists, IL-6, IL-8, IL-10, and IL-1Ra are among those that increase most during exercise. ${ }^{1-7} \mathrm{We}$ and other investigators have shown little or no exercise-induced increases for IL-2, IL-3, IL-4, IL-12, interferon- $\gamma$ (IFN- $\gamma$ ), TNF- $\alpha$, and IL- $1 \beta ., 7$

\section{MATERIALS AND METHODS}

\section{Subjects}

Twelve trained male cyclists were recruited as experimental subjects through local and collegiate cycling clubs. Written informed consent was obtained from each subject, and the experimental procedures were approved by the university institutional review board.

\section{Research design}

Two to three weeks prior to the first test session, subjects reported to the ASU Human Performance Laboratory for orientation and measurement of body composition and cardiorespiratory fitness. Body composition was assessed by hydrostatic weighing using an electronic load cell system (Exertech, Dresbach, MN), estimated residual volume, and the Siri equation. ${ }^{27}$ $\mathrm{VO}_{2 \max }$ was determined using a graded maximal protocol (25 $\mathrm{W}$ increase every $2 \mathrm{~min}$ starting at $150 \mathrm{~W}$ ) with the subjects using their own bicycles on CompuTrainer Pro Model 8001 trainers (RaceMate, Seattle, WA). Oxygen uptake and ventilation were measured using the MedGraphics CPX metabolic system (MedGraphics Corporation, St. Paul, MN). Heart rate was measured using a chest heart rate monitor (Polar Electro Inc., Woodbury, NY). Basic demographic and training data were obtained through a questionnaire.

Subjects agreed to avoid the use of large-dose vitamin/mineral supplements ( $>100 \%$ of recommended dietary allowances), nutritional supplements, ergogenic aids, herbs, and medications known to affect immune function for 1 week prior to test sessions. During orientation, a dietitian instructed the subjects to follow a diet moderate in carbohydrate during the 3 days prior to the test session and record intake in a food record. The food records were analyzed using a computerized dietary assessment program (Food Processor, ESHA Research, Salem, OR).

On test session dates, a standardized liquid meal (Boost Plus, Mead Johnson Nutritionals, Evansville, IN) was ingested at an energy level of $67 \mathrm{~kJ} \cdot \mathrm{kg}^{-1}\left(16 \mathrm{kcal} \cdot \mathrm{kg}^{-1}\right)$ body mass by subjects prior to 10:00 AM. Boost Plus is a nutritionally complete, high-energy oral supplement with an energy density of 6.4 $\mathrm{kJ} \cdot \mathrm{ml}^{-1}\left(1.52 \mathrm{kcal} \cdot \mathrm{ml}^{-1}\right)$ and contains $16 \%$ of energy as protein, $34 \%$ as fat, and $50 \%$ as carbohydrate. In quantities of 1000 $\mathrm{mL}$, Boost Plus exceeds daily value recommendations for all major vitamins and minerals.

Subjects came to the laboratory for two 2-h test sessions and ingested carbohydrate or placebo beverages in a randomized, counterbalanced design. The test sessions were 1-2 weeks apart. Subjects cycled for $2.0 \mathrm{~h}$ at $\sim 60 \%-65 \% \mathrm{Watts}_{\max }$. On test session dates, subjects reported to the laboratory at 3:00 PM, not having ingested energy in any form after 10:00 AM. Blood samples were collected $\sim 30$ min preexercise, immediately postexercise, and $1 \mathrm{~h}$ postexercise. Blood samples were drawn from an antecubital vein with subjects in the seated position. Experimental subjects ingested carbohydrate $\left(6 \%\right.$ or $\left.60 \mathrm{~g} \cdot 1^{-1}\right)$ or placebo beverages $15-30 \mathrm{~min}$ preexercise $\left(12 \mathrm{ml} \cdot \mathrm{kg}^{-1}\right)$ and during the 2 -h cycling bout $\left(4 \mathrm{ml} \cdot \mathrm{kg}^{-1} \cdot 15 \mathrm{~min}^{-1}\right)$. The beverages were supplied by the Gatorade Sports Science Institute (Barrington, IL). The carbohydrate and placebo beverages were identical in appearance and taste and in sodium $(\sim 19.0$ $\left.\mathrm{mEq} \cdot 1^{-1}\right)$ and potassium $\left(\sim 3.0 \mathrm{mEq} \cdot 1^{-1}\right)$ concentration and $\mathrm{pH}(\sim 3.0)$. No other beverages or food were ingested during the test sessions.

During the test sessions, subjects cycled using their own bicycles on trainers (CompuTrainer Pro Model 8001) with the exercise load set at $\sim 60 \%-65 \%$ maximal Watts and $\sim 75 \%$ $\mathrm{VO}_{2 \max }$. Metabolic measurements were made every $30 \mathrm{~min}$ of cycling using the MedGraphics CPX metabolic system to verify workload.

\section{Leukocyte mRNA extraction and cDNA synthesis}

The QIAampRNA Blood Mini Kit Protocol (Qiagen, Valencia CA) was used to extract mRNA. From each subject, two 1.5 -mL aliquots of whole blood collected in EDTA were puri-

Table 1. Subject Characteristics of Male Cyclists $(n=12)$

\begin{tabular}{lc}
\hline Variable & Value \\
\hline Age (years) & $21.0 \pm 1.0^{\mathrm{a}}$ \\
Height $(\mathrm{m})$ & $1.78 \pm 0.01$ \\
Body mass $(\mathrm{kg})$ & $71.6 \pm 1.9$ \\
Body composition $(\%$ fat) & $11.9 \pm 1.0$ \\
Heart rate, maximal (beats $\left.\cdot \mathrm{min}^{-1}\right)$ & $191 \pm 2$ \\
Power $_{\text {max }}(\mathrm{W})$ & $335 \pm 8$ \\
$\mathrm{Vo}_{2} \mathrm{max}\left(\mathrm{ml} \cdot \mathrm{kg}^{-1} \cdot \mathrm{min}^{-1}\right)$ & $56.9 \pm 1.3$ \\
Minute ventilation, maximal $\left(1 \cdot \mathrm{min}^{-1}\right)$ & $166 \pm 6$ \\
\hline
\end{tabular}

${ }^{\mathrm{a}}$ Mean $\pm \mathrm{SE}$. 
Table 2. Plasma Glucose, Insulin, Cortisol, and Epinephrine in 12 Cyclists Under Carbohydrate (C) and Placebo (P) Conditions Before and After 2 h of Intensive Cycling

\begin{tabular}{|c|c|c|c|c|}
\hline Variable & Preexercise & Postexercise & $\begin{array}{l}1 \mathrm{~h} \text { post- } \\
\text { exercise }\end{array}$ & $\begin{array}{c}\mathrm{p} \text { value: } \\
\text { interactions }\end{array}$ \\
\hline \multicolumn{5}{|c|}{ Glucose $\left(\mathrm{mmol} \cdot \mathrm{L}^{-1}\right)$} \\
\hline $\mathrm{C}$ & $5.52 \pm 0.13$ & $6.46 \pm 0.36^{*}$ & $6.15 \pm 0.43$ & \multirow[t]{2}{*}{$0.004 ; 0.510$} \\
\hline $\mathrm{P}$ & $5.38 \pm 0.15$ & $5.05 \pm 0.21$ & $4.90 \pm 0.11$ & \\
\hline \multicolumn{5}{|c|}{ Insulin $\left(\mathrm{pmol} \cdot \mathrm{L}^{-1}\right)$} \\
\hline $\mathrm{C}$ & $122 \pm 40.4$ & $226 \pm 51.9$ & $249 \pm 51.5^{*}$ & \multirow[t]{2}{*}{$0.050 ; 0.097$} \\
\hline $\mathrm{P}$ & $76.8 \pm 17.5$ & $97.5 \pm 21.4$ & $27.7 \pm 6.28$ & \\
\hline \multicolumn{5}{|c|}{ Cortisol $\left(\mathrm{mmol} \cdot \mathrm{L}^{-1}\right)$} \\
\hline C & $319 \pm 31$ & $347 \pm 52 *$ & $263 \pm 42 *$ & \multirow[t]{2}{*}{$<0.001 ; 0.042$} \\
\hline $\mathrm{P}$ & $303 \pm 30$ & $490 \pm 45$ & $434 \pm 51$ & \\
\hline \multicolumn{5}{|c|}{ Epinephrine $\left(\mathrm{pmol} \cdot \mathrm{L}^{-1}\right)$} \\
\hline $\mathrm{C}$ & $808 \pm 140$ & $734 \pm 120$ & $638 \pm 130$ & \multirow[t]{2}{*}{$0.049 ; 0.022$} \\
\hline $\mathrm{P}$ & $732 \pm 90$ & $1740 \pm 580$ & $771 \pm 110$ & \\
\hline
\end{tabular}

anteraction: The first $p$ value represents the condition (carbohydrate vs. placebo) $\times$ time $(3$ time points) interaction; the second $p$ value represents the overall time effect.

*Significant difference in change from preexercise in carbohydrate compared with placebo trials, $p<0.05$.

fied for RNA. Briefly, erythrocytes were selectively lysed, and leukocytes were recovered by centrifugation. Samples were briefly centrifuged through a QIAshredder spin column, ethanol was added to adjust binding conditions, and the sample was applied to a QIAamp spin column. RNA was bound to the silica gel membrane during a brief centrifugation step. Contaminants were washed away, and total RNA was eluted in $30 \mu \mathrm{L}$ of RNase-free water.

The extracted RNA (7.5 $\mu \mathrm{L}$ of sample) was dissolved in diethylpyrocarbonate-treated water and quantified spectrophotometrically at 260-nm wavelength. RNA was reverse transcribed into cDNA in a $50-\mu \mathrm{L}$ reaction volume containing $19.25 \mu \mathrm{l}$ RNA in RNase-free water, $5 \mu \mathrm{L} 10 \times$ RT buffer, $11 \mu \mathrm{L} 25 \mathrm{mM}$ $\mathrm{MgCl}_{2}, 10 \mu \mathrm{L}$ deoxyNTPs mixture, $2.5 \mu \mathrm{L}$ random hexamers, $1 \mu \mathrm{L}$ RNase inhibitor, and $1.25 \mu \mathrm{L}$ multiscribe reverse transcriptase $(50 \mathrm{U} / \mu \mathrm{L})$. Reverse transcription was performed at $25^{\circ} \mathrm{C}$ for $10 \mathrm{~min}, 37^{\circ} \mathrm{C}$ for $60 \mathrm{~min}$, and $95^{\circ} \mathrm{C}$ for $5 \mathrm{~min}$, followed by quick chilling on ice, and stored at $-20^{\circ} \mathrm{C}$ until subsequent amplification.

\section{Quantitative real-time PCR analysis}

Quantitative real-time polymerase chain reaction (PCR) analysis was done as per the manufacturer's instructions (Applied Biosystems, Foster City, CA) using TaqMan Gene Expression Assays. DNA amplification was carried out in 12.5 TaqMan Universal PCR Master Mix (AmpliTaq Gold DNA polymerase, passive reference 1, buffer, dNTPs, AmpErase UNG), $1 \mu \mathrm{L}$ cDNA, $9 \mu \mathrm{L}$ RNase-free water, and $1.25 \mu \mathrm{L} \mathrm{18S}$ primer (VIC) and $1.25 \mu \mathrm{L}$ primer (FAM) (for endogenous reference and target cytokine) in a final volume of $25 \mu \mathrm{L} /$ well. Human control RNA (calibrator RNA) was also used and served

Table 3. Plasma Cytokine Levels in 12 Cyclists Under Carbohydrate (C) and Placebo (P) Conditions Before and After 2 h of Intensive Cycling

\begin{tabular}{|c|c|c|c|c|}
\hline Variable & Preexercise & Postexercise & $\begin{array}{l}1 \text { h post- } \\
\text { exercise }\end{array}$ & $\begin{array}{c}\mathrm{p} \text { value: } \\
\text { interactions }\end{array}$ \\
\hline \multicolumn{5}{|c|}{ IL-6 $\left(\mathrm{pg} \cdot \mathrm{mL}^{-1}\right)$} \\
\hline C & $1.28 \pm 0.68$ & $14.6 \pm 2.44^{*}$ & $8.77 \pm 1.37 *$ & \multirow[t]{2}{*}{$0.007 ;<0.001$} \\
\hline $\mathrm{P}$ & $0.56 \pm 0.23$ & $23.0 \pm 4.70$ & $12.6 \pm 2.66$ & \\
\hline \multicolumn{5}{|c|}{$\mathrm{IL}-8\left(\mathrm{pg} \cdot \mathrm{mL}^{-1}\right)$} \\
\hline $\mathrm{C}$ & $5.53 \pm 0.73$ & $9.62 \pm 1.08$ & $10.3 \pm 0.73$ & \multirow[t]{2}{*}{$0.453 ;<0.001$} \\
\hline $\mathrm{P}$ & $4.93 \pm 0.41$ & $10.1 \pm 1.12$ & $10.2 \pm 0.86$ & \\
\hline \multicolumn{5}{|c|}{$\mathrm{IL}-1 \mathrm{Ra}\left(\mathrm{pg} \cdot \mathrm{mL}^{-1}\right)$} \\
\hline C & $202 \pm 56$ & $323 \pm 63$ & $624 \pm 275^{*}$ & \multirow[t]{2}{*}{$0.010 ; 0.061$} \\
\hline $\mathrm{P}$ & $184 \pm 22$ & $374 \pm 54$ & $1215 \pm 503$ & \\
\hline \multicolumn{5}{|c|}{$\mathrm{IL}-10\left(\mathrm{pg} \cdot \mathrm{mL}^{-1}\right)$} \\
\hline $\mathrm{C}$ & $1.67 \pm 0.14$ & $16.2 \pm 2.75^{*}$ & $16.5 \pm 4.06^{*}$ & \multirow[t]{2}{*}{$0.003 ;<0.001$} \\
\hline $\mathrm{P}$ & $1.83 \pm 0.11$ & $25.3 \pm 4.32$ & $48.9 \pm 13.8$ & \\
\hline
\end{tabular}

anteractions: The first $p$ value represents the condition (carbohydrate vs. placebo) $\times$ time $(3$ time points) interaction; the second $p$ value represents the overall time effect.

*Significant difference in change from preexercise in carbohydrate compared with placebo trials, $p<0.05$. 
as a calibrator for each plate. Samples were loaded in a MicroAmp 96-well reaction plate. Plates were run using the ABI Sequence Detection System. After $2 \mathrm{~min}$ at $50^{\circ} \mathrm{C}$ and $10 \mathrm{~min}$ at $95^{\circ} \mathrm{C}$, plates were coamplified by 50 repeated cycles, of which 1 cycle consisted of a 15 -sec denaturing step at $95^{\circ} \mathrm{C}$ and a 1-min annealing/extending step at $60^{\circ} \mathrm{C}$. Data were analyzed by ABI software using the cycle threshold (CT), which is the value calculated and based on the time (measured by PCR cycle number) at which the reporter fluorescent emission increases beyond a threshold level (based on the background fluorescence of the system), ${ }^{28}$ and it reflects the cycle number at which the cDNA amplification is first detected. We have previously reported detailed methodology concerning the dual amplification technique. ${ }^{2,3,9}$ Samples were run in duplicate, and the intraassay and interassay CVs were determined to be $1.69 \%$ and $1.65 \%$ for the $\Delta \mathrm{CTs}$, respectively.

\section{Calculations for relative quantification}

Quantification of cytokine gene expression for IL-8, IL-10, IL-1Ra, and IL-6 was calculated using the $\Delta \Delta \mathrm{CT}$ method as described by Livak and Schmittgen. ${ }^{29}$ This method uses a single sample, the calibrator sample, for comparison of every unknown sample's gene expression. This method of analysis and quantification has been shown to give similar results to the standard curve method. ${ }^{28}$ Briefly, $\Delta \mathrm{CT}$ (CT(FAM) - CT(VIC)) was calculated for each sample and calibrator. $\Delta \Delta \mathrm{CT}$ ( $\Delta \mathrm{CT}$ (calibrator) $\Delta \mathrm{CT}$ (sample)) was then calculated for each sample, and relative quantification was calculated as $2 \Delta \Delta \mathrm{CT}$. Initial exclusion criteria consisted of FAM CT $\geq 40$ and VIC CT $\geq 23$.

\section{Hormones, glucose}

Plasma concentrations of cortisol were determined using the competitive solid-phase ${ }^{125}$ I radioimmunoassay (RIA) technique (Diagnostic Products Corporation, Los Angeles, CA) with cortisol-specific antibody (Ab)-coated tubes (Coat-A-Count tubes). Intraassay (CVintra) and interassay (CVinter) coeffi-

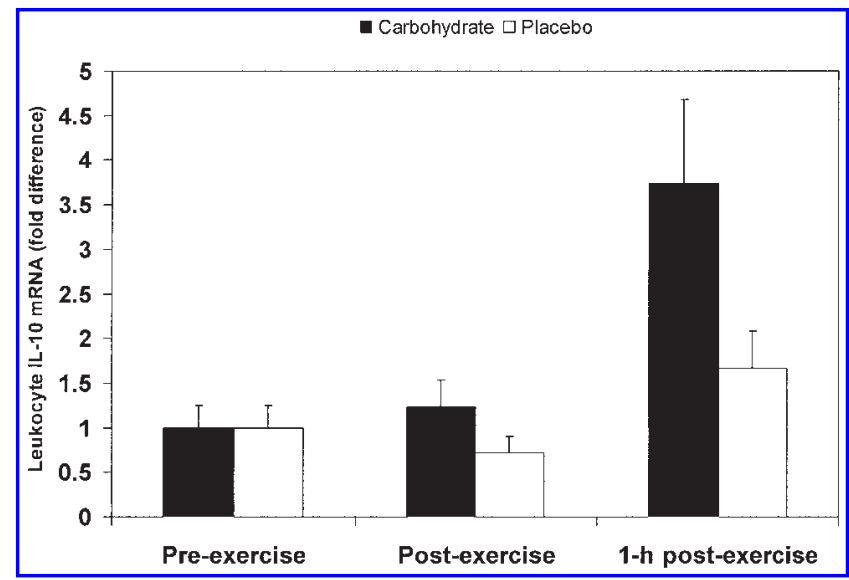

FIG. 1. IL-10 mRNA expression in blood leukocytes from cyclists during $2 \mathrm{~h}$ of cycling at $\sim 64 \%$ Watts $_{\max }$ under carbohydrate and placebo conditions. Values are expressed as a fold change from rest, with rest equal to 1 . Time effect, $p=0.001$; carbohydrate/placebo condition $\times$ time effect, $p=0.220$.

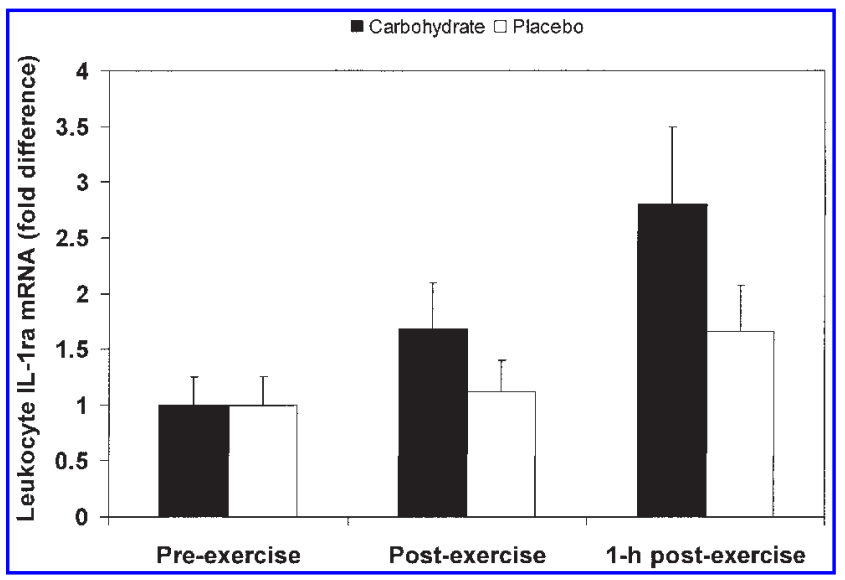

FIG. 2. IL-1Ra mRNA expression in blood leukocytes from cyclists during $2 \mathrm{~h}$ of cycling at $\sim 64 \%$ Watts $_{\max }$ under carbohydrate and placebo conditions. Values are expressed as a fold change from rest, with rest equal to 1 . Time effect, $p=0.003$; carbohydrate/placebo condition x time effect, $p=0.634$.

cients of variation were $4.5 \%$ and $5 \%$, respectively. Assay sensitivity was $5.5 \mathrm{nmol} / \mathrm{L}(0.2 \mu \mathrm{g} / \mathrm{dL})$. RIA kits were also used to determine plasma concentrations of insulin in duplicate according to the manufacturer's instructions (Diagnostic Products Corporation). CVintra and CVinter were $5 \%$ and $7 \%$, respectively. Assay sensitivity was $1.2 \mu \mathrm{g} / \mathrm{dL}$. For plasma epinephrine, blood samples were drawn into chilled tubes containing EGTA and glutathione and centrifuged, and the plasma was stored at $-80^{\circ} \mathrm{C}$ until analysis. Plasma concentrations of epinephrine were determined by competitive EIA (Labor Diagnostika Nord, Nordhorn, Germany) using the microtiter plate format as described previously. ${ }^{2}$ The CVintra and CVinter variation were $11 \%$ and $14 \%$, respectively. The sensitivity of this assay for plasma samples is $11 \mathrm{pg} / \mathrm{mL}$. Plasma glucose was analyzed spectrophotometrically using a glucose oxidase reagent (Randox Laboratories Ltd., Belfast, Northern Ireland) in a microtiter plate-based assay.

\section{Plasma cytokine measurements}

Total plasma concentrations of IL-1Ra, IL-6, IL-8, and IL-10 were determined using quantitative sandwich ELISA kits provided by R\&D Systems, Inc. (Minneapolis, MN). All samples and provided standards were analyzed in duplicate. The minimum detectable concentrations were IL-1Ra $<22 \mathrm{pg} \cdot \mathrm{mL}^{-1}$, IL-6 $<0.70$ $\mathrm{pg} \cdot \mathrm{mL}^{-1}$, IL-6 (high sensitivity) $<0.094 \mathrm{pg} \cdot \mathrm{mL}^{-1}$, IL-8 $<10$ $\mathrm{pg} \cdot \mathrm{ml}^{-1}$, and IL-10 $<3.9 \mathrm{pg} \cdot \mathrm{mL}^{-1}$. A high sensitivity kit was used to analyze IL-6 in the prerace plasma samples. Because of the lack of high-sensitivity kits for IL-8 and IL-10, we extrapolated data below the minimum detectable level using a software program suited to this task (SOFTmax, Molecular Devices, Sunnyvale, CA). Preexercise and postexercise samples for IL-8, IL-10, and IL-1Ra were analyzed on the same assay plate to decrease interkit assay variability.

\section{Statistical analysis}

Values were expressed as mean \pm SE. Performance measures across the two exercise trials were compared using paired 
$t$-tests. Data in Tables 2 and 3 and all figures were analyzed using a 2 (carbohydrate and placebo conditions) $\times 3$ (times of measurement) repeated-measures ANOVA. When Box's M suggested that the assumptions necessary for the univariate approach were not tenable, the multivariate approach to repeated measures ANOVA was used (Pillais trace). If the interaction $p$ value was $\leq 0.05$, the changes from preexercise to postexercise values were calculated and compared using paired $t$-tests, with statistical significance set at $p<0.05$.

\section{RESULTS}

Subject characteristics and results from the maximal cardiorespiratory tests for the 12 male cyclists are listed in Table 1. Three-day food records indicated no significant differences in macronutrient intakes between test sessions, with a mean energy intake of $13.1 \pm 0.9 \mathrm{MJ} \cdot$ day $^{-1}\left(3119 \pm 213 \mathrm{kcal} \cdot\right.$ day $\left.^{-1}\right)$ and a percent of energy intake of $60.2 \% \pm 2.6 \%$ carbohydrate, $27.5 \% \pm 1.9 \%$ fat, and $14.4 \% \pm 1.0 \%$ protein. Power output and heart rate did not differ between the two test sessions, and averaged $214 \pm 5 \mathrm{~W}\left(63.9 \pm 0.7 \% \mathrm{Watts}_{\max }\right), 159 \pm 3$ heart beats/min $\left(83.3 \pm 1.1 \% \mathrm{HR}_{\max }\right)$, and $73.6 \pm 1.5 \% \mathrm{Vo}_{2 \max }$.

Plasma glucose, insulin, cortisol, and epinephrine data are summarized in Table 2. Significant condition (carbohydrate vs. placebo) $\times$ time interaction effects were measured for each of these variables. Postexercise levels of glucose were higher in the carbohydrate than in the placebo trials $(17 \%$ vs. $-6.1 \%$, respectively), and levels of cortisol (8.8\% vs. 62\%, respectively) and epinephrine (-9.2\% vs. $138 \%$, respectively) were lower.

Plasma cytokine data are summarized in Table 3. Significant condition $\times$ time interaction effects were measured for IL-6, IL-1Ra, and IL-10 but not IL-8. In the carbohydrate compared with placebo trials, lower plasma levels were measured for IL6 (10-fold vs. 40-fold, respectively, immediately postexercise), IL-10 (8.9-fold vs. 26-fold, respectively, $1 \mathrm{~h}$ postexercise), and IL-1Ra (2.1-fold vs. 5.6-fold, respectively, $1 \mathrm{~h}$ postexercise).

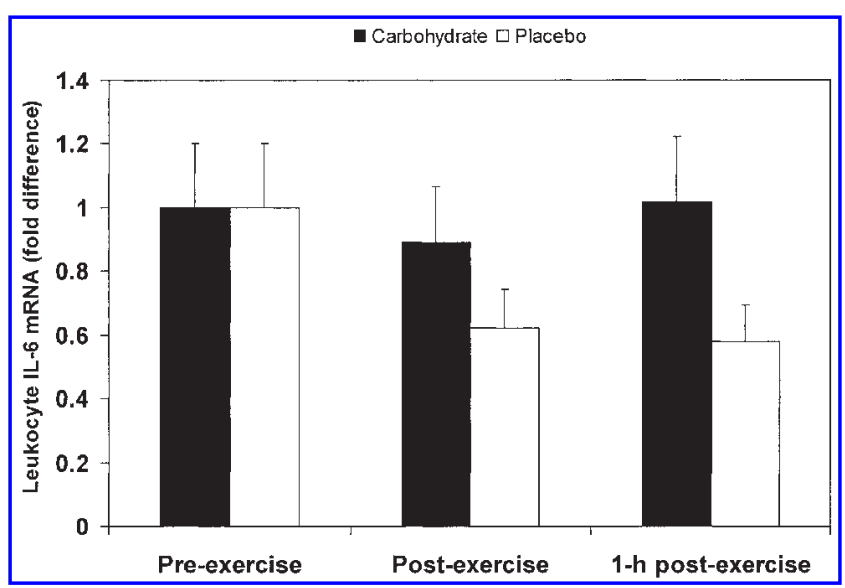

FIG. 3. IL-6 mRNA expression in blood leukocytes from cyclists during $2 \mathrm{~h}$ of cycling at $\sim 64 \%$ Watts $_{\max }$ under carbohydrate and placebo conditions. Values are expressed as a fold change from rest, with rest equal to 1 . Time effect, $p=0.040$; carbohydrate/placebo condition $\times$ time effect, $p=0.817$.

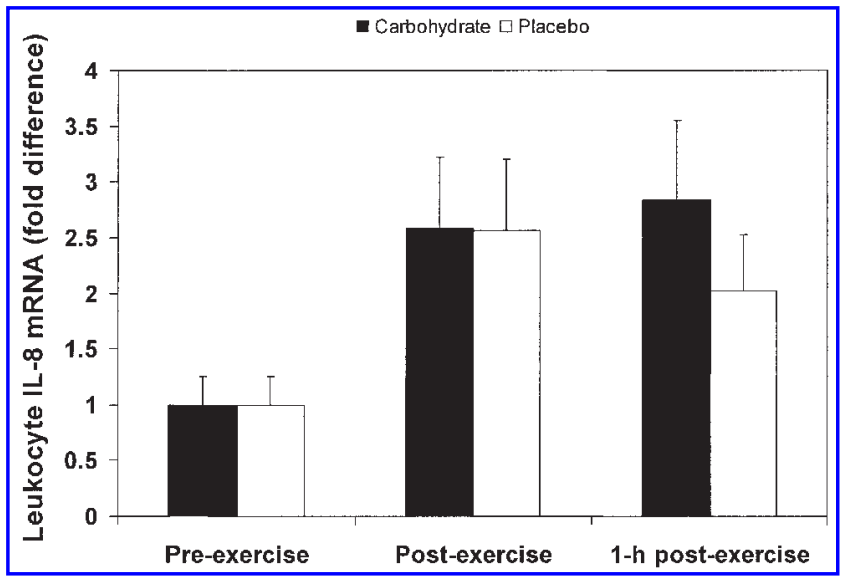

FIG. 4. IL-8 mRNA expression in blood leukocytes from cyclists during $2 \mathrm{~h}$ of cycling at $\sim 64 \%$ Watts $_{\max }$ under carbohydrate and placebo conditions. Values are expressed as a fold change from rest, with rest equal to 1 . Time effect, $p=0.003$; carbohydrate/placebo condition $\mathrm{x}$ time effect, $p=0.397$.

Figures 1, 2, 3, and 4 summarize the leukocyte mRNA data. Leukocyte mRNA expression for IL-10 (Fig. 1), IL-1Ra (Fig. 2), and IL-8 (Fig. 4) increased postexercise (time effects, $p=$ $0.001,2.7$-fold increase $1 \mathrm{~h}$ postexercise; $p=0.003,2.2$-fold increase; $p=0.003,2.4$-fold increase, respectively), but the pattern of change over time did not vary between the carbohydrate and placebo trials $(p=0.220, p=0.634, p=0.397$, respectively). Leukocyte mRNA expression for IL-6 (Fig. 3) decreased post-exercise (time effect, $p=0.040,0.8$-fold decrease) but did not differ by condition ( $p=0.817)$.

Mean $\Delta \mathrm{CT}$ values (combining preexercise and postexercise values) for IL-8, IL-10, IL-1Ra, and IL-6 were $12.5 \pm 0.2$, $21.6 \pm 0.2,14.7 \pm 0.2$, and $21.7 \pm 0.2$, respectively.

\section{DISCUSSION}

We determined that leukocyte mRNA expression for IL-8, IL-10, and IL-1Ra, but not for IL-6, increased postexercise to a similar degree during the carbohydrate and placebo cycling trials. Our data also indicate that exercise induced increases in plasma cortisol, epinephrine, IL-6, IL-1Ra, and IL-10 were attenuated when cyclists ingested carbohydrate compared with placebo beverages, confirming previously published findings from our laboratory and others. ${ }^{1-3,5,9,19,25,26}$

This is the first study to show that heavy exercise workloads increase mRNA content in blood leukocytes for IL-10, IL-1Ra, and IL-8, but not IL-6, under both carbohydrate and placebo conditions. The mechanisms involved in this disparity between the IL-6 response and other cytokines remain unclear at this time. Two other studies have shown that exercise does not induce IL-6 mRNA expression in blood mononuclear cells. ${ }^{10,14}$ The absolute abundance of IL-8, IL-1Ra, and IL-10 mRNA from blood leukocytes in our subjects was high (i.e., low mean $\Delta \mathrm{CT}$ values), indicating a substantial potential contribution to plasma cytokine levels. For the same amount of total mRNA, IL-8 and IL-10 mRNA abundance in blood leukocytes was well above levels we have previously reported from muscle biopsy 
samples. ${ }^{2,9}$ IL-8 was approximately 1000 -fold greater and IL10 was 128 -fold greater in the leukocyte pellets compared with the muscle biopsy samples. ${ }^{2}$ Despite the low numbers of leukocytes expected in postexercise muscle tissue, we propose that part of the IL-8 mRNA expression in this tissue is from the leukocytes.

The pattern of change in plasma IL-8 paralleled increases in blood leukocyte IL- 8 mRNA during both exercise trials, suggesting that gene expression and production and release of IL8 are regulated by factors related to exercise workload and not hormonal influences altered by carbohydrate or placebo ingestion. Previous research has indicated that IL-8, a chemotactic cytokine, is produced by multiple cell types, including endothelial cells, fat cells, mononuclear cells in blood, macrophages, and cells in bone, skin, and muscle. ${ }^{15} \mathrm{IL}-8$ is an important mediator of inflammatory disorders and stimulates polymorphonuclear cell adherence, degranulation, and respiratory burst activity. ${ }^{15}$ IL-8 is rapidly induced by many stimuli including, TNF- $\alpha$, IL-1, and bacterial agents, but whether these are important during exercise conditions is unknown.

Postexercise plasma levels of IL-1Ra, IL-10, and IL-6, however, did not parallel increases in blood leukocyte cytokine mRNA expression during both exercise trials. These data indicate that postexercise plasma IL-1Ra, IL-10, and IL-6 levels under carbohydrate/placebo conditions represent the cumulative effects of multiple factors that transpire following gene expression in several cell sources. Febbraio et al., ${ }^{19}$ for example, have shown that IL-6 release from the contracting muscle is decreased when subjects ingest carbohydrate compared with placebo beverages despite similar increases in muscle IL-6 mRNA, and they reasoned that IL-6 release is regulated by substrate availability. Most studies have shown that cycling exercise induces short-lived but significant increases in muscle mRNA for IL-6, IL-8, IL- $1 \beta$, and TNF- $\alpha$, and that increases are similar under carbohydrate compared with placebo conditions despite lower plasma IL-6 levels. 2,8,19,26 Thus, cytokine mRNA expression in blood leukocyte or muscle biopsy samples or both does not necessarily correspond with cytokine release or plasma cytokine levels.

In summary, our most important finding is that gene expression for IL-8, IL-10, and IL-1Ra, but not IL-6, is increased in blood leukocytes taken from athletes following $2 \mathrm{~h}$ of intensive cycling and is not influenced by carbohydrate compared with placebo ingestion. mRNA expression was high enough to indicate a substantial contribution of blood leukocytes to plasma levels of IL-8, IL-10, and IL-1Ra during prolonged exercise. Except for IL-8, however, postexercise plasma levels of these cytokines did not parallel blood leukocyte mRNA expression during each of the carbohydrate/placebo trials, indicating that cytokine production and release are influenced by posttranscriptional events or that cytokines are being produced and released from other cell types.

\section{ACKNOWLEDGMENTS}

This work was supported by a grant from the Gatorade Sports Science Institute. We acknowledge the skillful assistance of Nathaniel Bailey, Jessica Eaton, and Kevin Oley in this project.

\section{REFERENCES}

1. Nehlsen-Cannarella SL, Fagoaga OR, Nieman DC, Henson DA, Butterworth DE, Bailey E, Warren BJ, Davis JM. Carbohydrate and the cytokine response to 2.5 hours of running. J. Appl. Physiol. 1997;82:1662-1667.

2. Nieman DC, Davis JM, Henson DA, Gross SJ, Dumke CL, Utter AC, Vinci DM, Carson JA, Brown A, McAnulty SR, McAnulty LS, Triplett NT. Skeletal muscle cytokine mRNA and plasma cytokine changes after 2.5-h cycling: influence of carbohydrate. $\underline{\mathrm{Med}}$. Sci. Sports Exerc. 2005;37:1283-1290.

3. Nieman DC, Davis JM, Henson DA, Walberg-Rankin J, Shute M, Dumke CL, Utter AC, Vinci DM, Carson JA, Brown A, Lee WJ, McAnulty SR, McAnulty LS. Carbohydrate ingestion influences skeletal muscle cytokine mRNA and plasma cytokine levels after a 3-h run. J. Appl. Physiol. 2003;94:1917-1925.

4. Nieman DC, Dumke CL, Henson DA, McAnulty SR, Gross SJ, Lind RH. Muscle damage is linked to cytokine changes following a 160-km race. Brain Behav. Immun. 2005;19:398-403.

5. Nieman DC, Henson DA, Smith LL, Utter AC, Vinci DM, Davis JM, Kaminsky DE, Shute M. Cytokine changes after a marathon race. J. Appl. Physiol. 2001;91:109-114.

6. Nieman DC, Nehlsen-Cannarella SL, Fagoaga OR, Henson DA, Utter AC, Davis JM, Williams F, Butterworth DE. Influence of mode and carbohydrate on the cytokine response to heavy exertion. Med. Sci. Sports Exerc. 1998;30:671-678.

7. Suzuki K, Nakaji S, Yamada M, Totsuka M, Sato K, Sugawara K. Systemic inflammatory response to exhaustive exercise. Cytokine kinetics. Exerc. Immunol. Rev. 2002;8:6-38.

8. Chan MHS, Carey AL, Watt MJ, Febbraio MA. Cytokine gene expression in human skeletal muscle during concentric contraction: evidence that IL-8, like IL-6, is influenced by glycogen availability. Am. J. Physiol. Regul. Integr. Comp. Physiol. 2004;287:R322R327.

9. Nieman DC, Davis JM, Brown VA, Henson DA, Dumke CL, Utter AC, Vinci DM, Downs MF, Smith JC, Carson J, Brown A, McAnulty SR, McAnulty LS. Influence of carbohydrate ingestion on immune changes following $2 \mathrm{~h}$ of intensive resistance training. J. Appl. Physiol. 2004;96:1292-1298.

10. Ostrowski K, Rhode T, Zacho M, Asp S, Pedersen BK. Evidence that interleukin-6 is produced in human skeletal muscle during prolonged running. J. Physiol. 1998;508:949-953.

11. Penkowa M, Keller C, Keller P, Jauffred S, Pedersen BK. Immunohistochemical detection of interleukin-6 in human skeletal muscle fibers following exercise. FASEB J. 2003;17:2166-2168.

12. Steensberg A, Keller C, Starkie R, Osada T, Febbraio MA, Pedersen BK. IL-6 and TNF- $\alpha$ expression in, and release from, contracting human skeletal muscle. Am. J. Physiol. Endocrinol. Metab. 2002;283:E1272-1278.

13. Hiscock N, Chan MHS, Bisucci T, Darby IA, Febbraio MA. Skeletal myocytes are a source of interleukin-6 mRNA expression and protein release during contraction: evidence of fiber type specificity. FASEB J. 2004;18:992-994.

14. Moldoveanu AI, Shephard RJ, Shek PN. Exercise elevates plasma levels but not gene expression of IL-1 $\beta$, IL-6, and TNF- $\alpha$ in blood mononuclear cells. J. Appl. Physiol. 2000;89:1499-1504.

15. Lund T, Osterud B. The effect of TNF- $\alpha$, PMA, and LPS on plasma and cell-associated IL-8 in human leukocytes. Thromb. Res. 2004;113:75-83.

16. Akerstrom T, Steensberg A, Keller P, Keller C, Penkowa M, Pedersen BK. Exercise induces interleukin- 8 expression in human skeletal muscle. J. Physiol. 2005;563:507-516.

17. Steensberg A, Fischer CP, Keller C, Møller K, Pedersen BK. IL6 enhances plasma IL-1Ra, Il-10, and cortisol in humans. Am. J. Physiol. Endocrinol. Metab. 2003;285:E433-E437.

18. Bishop NC, Walker GJ, Bowley LA, Evans KF, Molyneux K, Wal- 
lace FA, Smith AC. Lymphocyte responses to influenza and tetanus toxoid in vitro following intensive exercise and carbohydrate ingestion on consecutive days. J. Appl. Physiol. 2005;99:1327-1335.

19. Febbraio MA, Steensberg A, Keller C, Starkie RL, Nielsen HB, Krustrup P, Ott P, Secher NH, Pedersen BK. Glucose ingestion attenuates interleukin-6 release from contracting skeletal muscle in humans. J. Physiol. 2003;549.2:607-612.

20. Green KJ, Croaker SJ, Rowbottom DG. Carbohydrate supplementation and exercise-induced changes in T-lymphocyte function. $J$. Appl. Physiol. 2003;95:1216-1223.

21. Henson DA, Nieman DC, Blodgett AD, Butterworth DE, Utter A, Davis JM, Sonnenfeld G, Morton DS, Fagoaga OR, NehlsenCannarella SL. Influence of exercise mode and carbohydrate on the immune response to prolonged exercise. Int. J Sport Nutr. 1999;9: 213-228.

22. Henson DA, Nieman DC, Nehlsen-Cannarella SL, Fagoaga OR, Shannon M, Bolton MR, Davis JM, Gaffney CT, Kelln WJ, Austin MD, Hjertman JME, Schilling BK. Influence of carbohydrate on cytokine and phagocytic responses to $2 \mathrm{~h}$ of rowing. $\underline{\mathrm{Med} \text {. Sci. }}$ Sports Exerc. 2000;32:1384-1389.

23. Henson DA, Nieman DC, Parker JCD, Rainwater MK, Butterworth DE, Warren BJ, Utter A, Davis JM, Fagoaga OR, NehlsenCannarella SL. Carbohydrate supplementation and the lymphocyte proliferative response to long endurance running. Int. J. Sports Med. 1998;19:574-580.

24. Henson DA, Nieman DC, Pistilli EE, Schilling B, Colacino A, Utter AC, Fagoaga OR, Vinci DM, Nehlsen-Cannarella SL. Influence of carbohydrate and age on lymphocyte function following a marathon. Int. J. Sport Nutr. Exerc. Metab. 2004;14:308-322.

25. Nieman DC, Henson DA, Garner EB, Butterworth DE, Warren BJ, Utter A, Davis JM, Fagoaga OR, Nehlsen-Cannarella SL. Carbo- hydrate affects natural killer cell redistribution but not activity after running. Med. Sci. Sports Exerc. 1997;29:1318-1324.

26. Starkie RL, Arkinstall MJ, Koukoulas I, Hawley JA, Febbraio MA. Carbohydrate ingestion attenuates the increase in plasma interleukin-6, but not skeletal muscle interleukin-6 mRNA, during exercise in humans. J. Physiol. 2001;533:585-591.

27. Siri WE. Body composition from fluid spaces and density: analysis of methods. In: Brozek J, Henschel A, eds. Techniques for Measuring Body Composition. Washington, DC: National Academy of Science, 1961:223-244.

28. Winer J, Jung CKS, Shackel I, Williams PM. Development and validation of real-time quantitative reverse-transcriptase-polymerase chain reaction for monitoring gene expression in cardiac myocytes in vitro. Anal. Biochem. 1999;270:41-49.

29. Livak KJ, Schmittgen TD. Analysis of relative gene expression data using real-time quantitative PCR and the $2^{-\Delta \Delta} C_{t}$ method. Methods 2001;25:402-408.

Address reprint requests or correspondence to:

Dr. David C. Nieman

Department of Health, Leisure, \& Exercise Science

P.O. Box 32071

Appalachian State University

Boone, NC 28608

Tel: (828) 262-6318

Fax: (828) 262-3138

E-mail: niemandc@appstate.edu

Received 30 January 2006/Accepted 20 March 2006 


\section{This article has been cited by:}

1. Asghar Abbasi, Melanie Hauth, Michael Walter, Jens Hudemann, Veit Wank, Andreas M. Niess, Hinnak Northoff. 2013. Exhaustive exercise modifies different gene expression profiles and pathways in LPS-stimulated and un-stimulated whole blood cultures. Brain, Bebavior, and Immunity . [CrossRef]

2. Karlie A. Intlekofer, Carl W. Cotman. 2013. Exercise counteracts declining hippocampal function in aging and Alzheimer's disease. Neurobiology of Disease 57, 47-55. [CrossRef]

3. C. Bernecker, J. Scherr, S. Schinner, S. Braun, W. A. Scherbaum, M. Halle. 2013. Evidence for an exercise induced increase of TNF- $\alpha$ and IL-6 in marathon runners. Scandinavian Journal of Medicine \& Science in Sports 23:2, 207-214. [CrossRef]

4. Wataru Aoi, Yuji Naito, Toshikazu YoshikawaImmune Function, Nutrition, and Exercise 83-93. [CrossRef]

5. David W. Horohov, Stephen T. Sinatra, Raj K. Chopra, Stanley Jankowitz, Alejandra Betancourt, Richard J. Bloomer. 2012. The Effect of Exercise and Nutritional Supplementation on Proinflammatory Cytokine Expression in Young Racehorses During Training. Journal of Equine Veterinary Science 32:12, 805-815. [CrossRef]

6. David C. Nieman, Manuela Konrad, Dru A. Henson, Krista Kennerly, R. Andrew Shanely, Sandra J. Wallner-Liebmann. 2012. Variance in the Acute Inflammatory Response to Prolonged Cycling Is Linked to Exercise Intensity. Journal of Interferon \& Cytokine Research 32:1, 12-17. [Abstract] [Full Text HTML] [Full Text PDF] [Full Text PDF with Links]

7. E. Angela Murphy, J. Mark Davis, Jamie L. McClellan, Martin D. Carmichael, Nico Van Rooijen, J. David Gangemi. 2011. Susceptibility to Infection and Inflammatory Response Following Influenza Virus (H1N1, A/PR/8/34) Challenge: Role of Macrophages. Journal of Interferon \& Cytokine Research 31:6, 501-508. [Abstract] [Full Text HTML] [Full Text PDF] [Full Text PDF with Links]

8. Young-Oh Shin, Jeong-Beom Lee. 2011. Effects of exercise training on plasma cytokine and chemokine levels, and thermoregulation. Journal of Thermal Biology 36:4, 219-224. [CrossRef]

9. Abbass Ghanbari-Niaki, Marziyeh Saghebjoo, Mehdi Hedayati. 2011. A single session of circuit-resistance exercise effects on human peripheral blood lymphocyte ABCA1 expression and plasma HDL-C level. Regulatory Peptides 166:1-3, 42-47. [CrossRef]

10. Marián Bobovčák, Renata Kuniaková, Ján Gabriž, Juraj Majtán. 2010. Effect of Pleuran ( $\beta$-glucan from Pleurotus ostreatus ) supplementation on cellular immune response after intensive exercise in elite athletes. Applied Physiology, Nutrition, and Metabolism 35:6, 755-762. [CrossRef]

11. David C. Nieman. 2009. Immune Function Responses to Ultramarathon Race Competition. Medicina Sportiva 13:4, 189-196. [CrossRef]

12. Alan R. Light, Andrea T. White, Ronald W. Hughen, Kathleen C. Light. 2009. Moderate Exercise Increases Expression for Sensory, Adrenergic, and Immune Genes in Chronic Fatigue Syndrome Patients But Not in Normal Subjects. The Journal of Pain 10:10, 1099-1112. [CrossRef]

13. Mary F. Barbe, Melanie B. Elliott, Samir M. Abdelmagid, Mamta Amin, Steven N. Popoff, Fayez F. Safadi, Ann E. Barr. 2008. Serum and tissue cytokines and chemokines increase with repetitive upper extremity tasks. Journal of Orthopaedic Research 26:10, 1320-1326. [CrossRef]

14. DAVID C. NIEMAN, DRU A. HENSON, MARY McMAHON, JENNA L. WRIEDEN, J. MARK DAVIS, E. ANGELA MURPHY, SARAH J. GROSS, LISA S. MCANULTY, CHARLES L. DUMKE. 2008. $\beta$-Glucan, Immune Function, and Upper Respiratory Tract Infections in Athletes. Medicine \& Science in Sports \& Exercise 40:8, 1463-1471. [CrossRef]

15. David C Nieman. 2008. Immunonutrition support for athletes. Nutrition Reviews 66:6, 310-320. [CrossRef]

16. David C. Nieman. 2008. RESPONSE. Medicine \& Science in Sports \& Exercise 40:4, 776. [CrossRef]

17. Stephen J Carp, Ann E Barr, Mary F Barbe. 2008. Serum biomarkers as signals for risk and severity of work-related musculoskeletal injury. Biomarkers in Medicine 2:1, 67-79. [CrossRef]

18. David C. Nieman, Dru A. Henson, J. Mark Davis, Charles L. Dumke, Sarah J. Gross, D. Paul Jenkins, E. Angela Murphy, Martin D. Carmichael, John C. Quindry, Steven R. McAnulty, Lisa S. McAnulty, Alan C. Utter, Eugene P. Mayer. 2007. Quercetin Ingestion Does Not Alter Cytokine Changes in Athletes Competing in the Western States Endurance Run. Journal of Interferon o. Cytokine Research 27:12, 1003-1012. [Abstract] [Full Text PDF] [Full Text PDF with Links] 